\title{
EL PROBLEMA DE LA INMACULADA CONCEPCIÓN EN LA SEGUNDA DÉCADA DEL SIGLO XVII. FESTEJOS Y MÁSCARAS: EL PAPEL DE LOS PLATEROS
}

\author{
POR MARÍA JESÚS SANZ
}

La problemática de la Concepción Inmaculada de María alcanzó un punto álgido entre 1615 y 1617. la ciudad de sevilla fue escenario de una enconada lucha entre los defensores de la Inmaculada -órdenes religiosas, arzobispo y ciudadanos-, y los detractores -Orden Dominica-. Con tal motivo se celebraron fiestas, procesiones y mascaradas, destacando entre todas ellas la que organizó el gremio de Plateros, considerada en su tiempo como la mejor.

The polemics about the Inmaculate Conception reached a culminating point between the years of 1614 and 1617. The city of Seville was the scene of a confrontation between the upholdres of the Inmaculate Conception -Religious Orders, Archbishop and citizens-, and its detractors -de Dominican Order-. In that context several feasts, processions and masquerades took place. Among this, the masquerade of the Silversmiths Corporation stood out and it was regarded as the best one.

El misterio de la Concepción Inmaculada de María, declarado Dogma de fe por la Iglesia Católica en 1854, no supuso ninguna novedad, ni despertó apasionamiento en el momento en que el Papa Pio IX lo proclamó, ya que era un concepto aceptado unánimemente por la Cristiandad.

Parece ser que la creencia en la Concepción Inmaculada de la Virgen procede de la Iglesia Oriental, que celebraba esta festividad antes del siglo VIII, y a la que ya San Agustín se mostró contrario ${ }^{1}$. Sin embargo, a lo largo de la Edad Media la devoción se extendió por Occidente celebrándose la festividad en los distintos países europeos, aunque no de una manera generalizada, y despertando a su vez fuertes

1. Stratton, S.: La Inmaculada Concepción en el Arte Español, Madrid, 1989, pág.4. 
controversias. San Bernardo fue uno de los contrarios a la Concepción Inmaculada, pues defendía, que la Virgen fue primero concebida, y luego santificada. En la misma línea, y con opiniones aún más contundentes se movía Santo Tomás, creador de la filosofía Tomista, y cabeza pensante de la orden dominica.

En el polo opuesto se hallaban los franciscanos, seguidores de Duns Scoto y defensores de la ausencia de Pecado Original en María desde el mismo momento de su concepción, y no en un momento posterior como pretendían los dominicos. Todas estas divergencias teológicas tuvieron una obligada confrontación en el Universidad de Paris a lo largo de los siglos XIII y XIV.

Es España, parece ser que en el Reino de Aragón la defensa de la Inmaculada fue asumida por la corona, y desde Juan I hasta Fernando el Católico los consejos y las leyes reales animaron a los ciudadanos en este sentido, llegando en algunos casos a prohibir que se predicara en sus reinos la doctrina contraria a la Concepción Inmaculada.

En el caso de Sevilla, aunque alguna autora sitúa la primera procesión en honor de la Inmaculada en $1369^{2}$, se tienen noticias muy anteriores sobre la devoción y festividad de la Concepción de María, pues en un misal de rito Hispalense datable a fines del siglo XIII, y desde luego anterior a 1311, se registra la fiesta de la Concepción con su octava ${ }^{3}$. Otros misales de la segunda mitad del XIV y del XV, tanto de rito Hispalense como Romano, continúan reseñando una fiesta propia para la Concepción ${ }^{4}$.

A partir de la unión de Castilla y Aragón los reyes de España se pronunciaron siempre a favor de la Inmaculada, ya que profesaban tradicionalmente una especial devoción a la Concepción de María.

La representación de la Concepción se puede rastrear ya en la iconografía de finales del siglo XV y de los inicios del XVI donde la Virgen aparece adolescente, sin el Niño, en actitud de orar, rodeada de aureola y de los símbolos de sus letanías, presidiendo la escena Dios Padre. En otros casos en lugar de Dios Padre aparecía la Trinidad en el momento de coronar a la Virgen. Esta representación se conocía con el nombre de "Tota Pulcra" porque, en bastantes casos se acompañaba de una leyenda que decía "Tota pulchra est amica mea, et macula non est in te". La frase tomada del Cantar de los Cantares fue curiosamente aplicada a la Virgen por San Bernardo, e identificada posteriormente con la Inmaculada ${ }^{5}$. Sin embargo, la palabra española no se generalizará y aceptará hasta comienzos del siglo XVII, siendo el título habitual el de Concepción. Con respecto a los colores del vestido y manto seguirán siendo los tradicionales de rojo y azul, hasta que Vicente Maçip, en el

2. Ibidem, pág.10.

3. Serrano y Ortega, M.: Glorias Sevillanas. Noticia histórica de la devoción y culto, que la muy noble y muy leal ciudad de Sevilla ha profesado a la Inmaculada Concepción de la Virgen María, desde los tiempos de la Antigüedad hasta la presente época, Sevilla, 1989, pág.44, fig.1.

4. Ibidem, pág. 44 y ss.

5. Stratton, S.: ob.cit., pág.35. 
segundo cuarto del siglo la vista de blanco y azul y la rodee de los símbolos de las Letanías ${ }^{6}$. A partir de este momento esta iconografía se extiende cada vez más, aunque todavía a lo largo del siglo XVI, y comienzos del XVII, se representan muchas imágenes de la Concepción vestidas de rojo y azul, es decir, con los colores tradicionales usados por la Virgen (fig.1).

A pesar de no existir una declaración sobre la Concepción Inmaculada, hay ya en el siglo XVI una devoción a la Concepción de María, y asímismo conventos y monasterios femeninos bajo esta advocación. De este modo las imágenes de la Virgen sin el Niño, orante y adolescente, son cada vez mas abundantes, aunque naturalmente el culto a la Virgen Madre con el Niño en los brazos, o a las Dolorosas tenga mayor extensión.

Esta conciencia popular de la devoción a la Inmaculada alentada inicialmente por los Franciscanos, como ya vimos, se extendió a lo largo del siglo XVI a otras muchas órdenes, como Carmelitas, Mercedarios y Jesuitas, que pronto la hicieron suya, e hicieron causa común frente a los dominicos, que siguieron fieles a los dictados de la gran figura de su orden, Santo Tomás.

En las primeras décadas del siglo XVII las antiguas confrontaciones teológicas de la Sorbona tuvieron un nuevo escenario en Sevilla, y en este caso la controversia salió a la calle tomando parte el ella toda la ciudad. El problema surgió en septiembre de 1613, a causa del sermón de un fraile dominico en el que pronunció la frase escandalosa: "La Virgen fue concebida y luego santificada" 7 . Esta frase aparentemente inocente conllevaba la eterna idea de que la Virgen no fue concebida sin pecado, sino que, después de haber sido concebida en él, fue santificada y desapareció la culpa original de ella.

Esto provocó una gran conmoción en la ciudad, alentada por las opiniones contrarias de franciscanos, mercedarios, jesuítas, carmelitas, etc., es decir todas las órdenes religiosas, e incluso del mismo arzobispo Don Pedro de Castro y del cabildo eclesiástico, que reaccionaron inmediatamente en contra y ordenaron funciones de desagravio. No es de extrañar pues, que este litigio, levantado en la ciudad entre los teólogos de las órdenes religiosas, afectara también al pueblo, que tomó parte activa en las controversias ${ }^{8}$.

El clima de enfrentamiento entre los presupuestos teológicos defendidos por los dominicos y las demás órdenes religiosas debía estar ya candente, pues la chispa saltó por esta sencilla frase. Los partidarios de la Inmaculada, que eran la mayoría, organizaron una solemne procesión a finales de este año -1613-, que salió del Sagrario y recorrió

6. Albi, J.: Juan de Juanes y su círculo, Valencia, 1979, y Joan de Joanes, Exposición, Madrid, 1979.

7. Ortíz de Zúñiga, D.: Anales eclesiásticos y seculares de la muy noble y muy leal ciudad de Sevilla, Sevilla 1796, edic. facs. 1988, tomo IV, pág. 235.

8. A este respecto hay que decir que para la historia de la tensión existente en Sevilla en estas fechas, contamos con el testimonio de una carta anónima, dirigida desde Sevilla a Madrid, por un partidario de los Inmaculistas, que nos cuenta multitud de acontecimientos y anécdotas de las ocurridas en Sevilla por estas fechas. Véase Vranic, S.: "Carta de un ciudadano de Sevilla: La guerra mariana de Sevilla en el siglo XVI", Archivo Hispalense, Sevilla, 1966, tomo XLIV, págs.241-274, y tomo XLV, págs.59-77. 
toda la ciudad cantando unos populares versos obra de Miguel del Cid, que realizó por encargo del canónigo Mateo Vázquez de Leca ${ }^{9}$, y que dicen así:

"Todo el mundo en general/ A voces Reyna escogida,

Diga que sois concebida/Sin pecado original".

A lo largo del siguiente año siguieron las fiestas en casi todas las parroquias y conventos de Sevilla, a las que se unieron los gremios, las cofradías, las comunidades de extranjeros -flamencos, franceses, portugueses, genoveses, etc.-, así como los hombres de color -negros y mulatos-e incluso los infieles, ya que parece ser que "los moros y moras pidieron licencia para hacer su fiesta", pero a estos no se les permitió ${ }^{10}$.

Toda esta reacción incial se vió sustentada por una serie de apariciones que tuvieron un seglar y dos eclesiásticos: Gómez Camacho, Bernardo del Toro, y Francisco de Santiago. Estos dos últimos unidos a Mateo Vázquez de Leca se encargaron de predicar por toda la ciudad sus conviciones, repartiendo la copla -que había escrito Miguel del Cid, y puesto música Bernardo del Toro-, por la escuelas de Sevilla para que los niños la cantasen, y ello fue aceptado de tal manera que contagió a toda la ciudad, que cantaba sin cesar la copla.

Del año 1616 data un cuadro de Juan de Roelas, existente en el Museo de Valladolid ${ }^{11}$, que muestra el clima religioso de Sevilla, cuyos habitantes se apiñan bajo los pies de la Inmaculada (fig.2). Allí Roelas ha colocado, en la parte superior, a la Inmaculada, aún vestida de rojo y azul, rodeada de santos y profetas, que anunciaban o defendían el misterio, y de los emblemas de las letanías, es decir al mundo celestial. En la parte baja por el contrario coloca al mundo terrenal, y ese mundo terrenal es una ciudad donde de aprecia -de izquierda a derecha-, un gran arco de triunfo, probablemente efímero, con Scoto y Laínez en sus jambas, que deja ver al fondo un paisaje boscoso con una fuente de tres tazas. A continuación del arco aparecen una serie de edificaciones entre las que se aprecia un arco ojival y una torre. El paisaje se interrumpe por una guirnalda floral, continuando hacia al lado derecho con un paisaje puramente urbano en el que se aprecian casas de varios pisos y unas gradas con columnas, que podrían ser una abstración de las Gradas, hoy día calle Alemanes. Desde el fondo del cuadro y atravesando el arco de triunfo discurre la procesión, en la que se aprecia un paso con palio, probablemente el de la Virgen de Los Reyes, ciriales, estandartes, y una gran multitud que lleva velas, palmas y papeles con las letras que van cantando. Se ha identificado este paisaje como una

9. La obra más completa sobre este personaje es la de Hazañas y La Rúa: Vázquez de Leca. 15731649, Sevilla, 1918.

10. Ortíz de Zúñiga, D.: ob.cit., pág.238.

11. Martín González, J.J.: El artista en la sociedad española del siglo XVII, Madrid, 1984, págs. 125 y 126, Valdivieso, E. y Serrera, J.M.: Pintura sevillana del primer tercio del siglo XVII, Madrid, 1985, pág.119 y láms.110, 111 y 112. 
vista de Roma con el simbolismo de la "Civitas Dei" de San Agustín ${ }^{12}$, hecho absolutamente aceptable, pero habría que pensar que quizá Roelas pretendiera identificar esta ciudad con Sevilla, la ciudad que veneraba a María sobre todas las demás. Sin embargo, quizá lo más interesante es la multitud abigarrada compuesta por toda clase de personajes: eclesiásticos y seglares, caballeros y vecinos, mujeres, niños, blancos y negros, etc..., todos apiñados cantando, desfilando o contemplando la procesión, en la que destacan los niños cantores, tantas veces aludidos en los textos. El lienzo lleva multitud de leyendas aclaratorias de los personajes, o de los símbolos que lo componen, pero uno de ellos, el más largo, explica perfectamente el contenido de la representación, cuyo texto dice así:

"En el año del Señor de 1615, a 29 de/ Junio, día del gran vicario de Cristo y príncipe de los Apóstoles, San Pedro, gobernando/ la silla apostólica Paulo V, y reinando en España/ el muy católico y poderoso rey don Felipe III/ de su nombre, siendo arzobispo de Sevilla el Illmo./ Sr. Don Pedro de Castro y Quiñones, y asistente don/ Diego Sarmiento de Sotomayor, conde de Salva/ tierra, inspiró Dios Nuestro Señor los corazones de todos los vecinos de Sevilla,/que acudieron a su iglesia mayor donde/ salieron cantando" "todo el mundo en general a vo/ ces Reina escogida dicen que sois concebida sin peca/ do original"". Los frailes de San Francisco y Descalzos de/ San Diego, los de la Merced y sus descalzos, los de/ Nuestra señora del Carmen y sus Descalzos, los de San Beni/ to, los de San Basilio, los de la Santísima Trinidad y sus Descalzos, los padres de la Compañía de Jesús, los/ de la Capacha y Terceros de San Francisco, mas veinte/ mil seglares. Caballeros de Santiago, de Alcántara/ de Calatrava, duques, condes y marqueses, todos iban ala/ bando la Inmaculada Concepción de la Virgen Nuestra Señora/ concebida sin mancha de pecado original, todo el cle/ ro, con muchos colegiales de la Universidad de/ ella, ibamos cantando con el mayor regocijo y devoción" 13 .

Realmente puede decirse que es la única imágen gráfica que tenemos del acontecimiento, y por lo tanto de un enorme valor.

No obstante, no todo acabó con esta impresionante manifestación de fervor inmaculadista, sino que se siguió adelante para intentar que tanto las máximas autoridades eclesiásticas como las seculares se unieran a este sentir unánime del pueblo de Sevilla. Así se comisionó a Mateo Vázquez de Leca y a Rodrigo de Toro

12. Valdivieso, E.: Juan de Roelas, Sevilla, 1978, págs.56-60.

13. Valdivieso, E.: ob.cit., págs. 56 y 57 . Este autor advierte que ha modemizado la inscripción, pero su lectura es absolutamente correcta. Stratton, que recoge también la leyenda del cuadro, lo hace incorrectamente pues además de cambiar algunas consonantes, se salta algún renglón, por lo que la lectura resulta incomprensible y además confunde el nombre del arzobispo de Sevilla con el del Asistente de la ciudad. Véase ob.cit., pág. 62. 
para que fuesen a Roma, con cartas del rey y del arzobispo, y consiguiesen una declaración del papa, a la sazón Paulo $\mathrm{V}$.

El 26 de julio de 1615 salen de Sevilla con su séquito y recorren la ciudad cantando la consabida copla, camino de Madrid, donde esperaban contar con la aprobación real. Después de detenerse en la Corte hasta el año siguiente, en que consiguieron del rey -Felipe III- la aprobación y las cartas favorables para el Papa, parten hacia Roma donde se demorarán durante algún tiempo hasta conseguir la aprobación deseada.

En agosto de 1617 el Papa dió un breve favorable a lo pedido, y desde que la noticia llegó a Sevilla se sucedieron grandes fiestas que se hallan ampliamente descritas, así como todos los detalles del proceso, por varios cronistas ${ }^{14}$. No obstante, como ya hemos visto, antes de conocer la opinión favorable de Roma, y como desagravio a la duda del fraile dominico sobre la Concepción Inmaculada, ya se habian organizado procesiones, máscaras, toros, etc., por los distintos conventos, parroquias, gremios, cofradías y nacionalidades de la ciudad, en las que expresaron su adhesión a la Inmaculada. Todas estas manifestaciones continuaron a lo largo de los años siguientes y tuvieron su momento culminante en los días 7 y 8 de diciembre de 1617 , en que, después de recibida la notificación favorable de Roma, se confirmó ese día para la fiesta de la Inmaculada.

El clima favorable a la defensa de la Inmaculada se extendió a los principales ciudades españolas, celebrádose cultos religiosos con sus sermones correspondientes, desfiles, máscaras y toda clase de manifestaciones populares, aunque no parece que en ninguna de estas ciudades se alcanzara el climax de Sevilla. Tenemos referencias de fiestas celebradas en Toledo, en Alcalá de Henares, en Jerez de la Frontera, pero de hecho existen folletos referidos a estas fiestas en otras muchas ciudades. Bastantes años más tarde -en 1652- todavía se hallaban los ánimos exaltados pues se conoce un incidente que hubo con los Dominicos en Madrid, donde su pobre convento de madera ardió, y la gente lo achacó a su oposición a la defensa de la Inmaculada, intentado incluso arrebatarles algunas de sus imágenes ${ }^{15}$.

Todo este movimiento teológico desarrollado, entre 1615 y 1617 , estuvo siempre teñido de un gran apasionamiento, en el que todos se sentían obligados a defender el misterio, que no dogma, ya que no lo era en ese momento. Así, surgieron multitud de sermones, diálogos, apologías y poemas laudatorios que se imprimeron en folletos y circularon por las ciudades. A todos estos escritos dogmáticos y literarios se añadieron otros folletos con la descripción de las fiestas, tanto religiosas como profanas, que se celebraron en las distintas ciudades ${ }^{16}$.

Muchos de estos folletos se encuadernaron posteriormente y se guardaron en las bibliotecas de los conventos, y gracias a ello hoy podemos conocerlos. Un tomo

14. Un repertorio de interés se halla en el reciente trabajo de Ros, C.: La Inmaculada y Sevilla, Sevilla, 1994.

15. Ortíz de Zúñiga, D.: ob.cit., tomo V, págs.108, 109.

16. Además de los recogidos en la obra de Carlos Ros, ya citada, puede consultarse el estudio de carácter general de Alenda y Mira, G.: Relaciones de la solemnidades y fiestas públicas en España, Madrid, 1903, y Ortíz de Zúñiga, D.: ob.cit., tomo IV, págs.253-254. 
de este tipo debió encuademarse en Sevilla, ya que la mayoría de los festejos se refieren a esta ciudad, aunque también se recogen los de otros lugares como Toledo, Alcalá de Henares, Jerez de la Frontera o París, conociéndose de él dos ejemplares, uno en la B.N., y otro en la B.C.C. de Sevilla.

Naturalmente todos estos impresos respondían a las celebraciones que la ciudad había hecho con motivo de la declaración papal sobre la Inmaculada, en 1617, y que resultaron grandes festejos, consistentes en cultos en las iglesias, procesiones de religiosos, máscaras que conjuntaban lo religioso con lo profano, fiestas de toros y fuegos artificiales. Dentro de las mascaradas, en la que participaron distintas corporaciones de la ciudad, la de los Plateros fue considerada por muchos cronistas como la mejor, o al menos una de las mejores que desfilaron por la ciudad, en este año de 1617 .

De la descripción de esta procesión festiva se conservan dos versiones impresas, una en prosa, que se halla dentro de los relatos generales de todas las máscaras (doc. $n^{\circ} 1$ ), y otra en verso, que refiere únicamente la mascarada de los plateros, lo que hace pensar que fue editada por ellos (doc. ${ }^{\circ} 2$ ). Ambos documentos van fechados en $1617^{17}$.

\title{
1. LA MASCARADA EN PROSA.
}

El cronista de la mascarada completa dedica su obra a Don Juan de la Cueva y Mendoza, Capitán General y gentilhombre del Rey, al que agradece, al final del relato, el que haya traído tantos tesoros de América, gracias a los cuales se ha podido hacer semejante demostración.

En la mascarada, puntualmente descrita en sus personajes, con sus vestidos, sombreros, banderas, etc., intervinieron seis cuadrillas, que el cronista llama copias. Estas las formaban:

\author{
$1^{a}$ Cirujanos y Barberos \\ $2^{\mathrm{a}}$ Mercenarios \\ $3^{\mathrm{a}}$ Mercaderes de Seda \\ $4^{\mathrm{a}}$ Jóvenes religiosos Mercedarios \\ $5^{\text {a }}$ Sederos y Gorreros \\ $6^{\mathrm{a}}$ Plateros.
}

17. Pérez Cabañas, A.: Fiestas del patronato de la Concepción, Sevilla, 1617, Biblioteca Capitular y Colombina, Sevilla; Copia sexta que da cuenta de mascarada que los artistas plateros hizieron, Sevilla, por Gabriel Ramos Bejarano, en cal de Génova, en este año de 1617, Madrid, Biblioteca Nacional, y Sevilla, Biblioteca Capitular y Colombina. Estos impresos se hallan encuadernados en un amplio tomo, con otros referidos también al tema de la Immaculada, de los que conocemos dos ejemplares, uno en la Biblioteca Colombina de Sevilla, y otro en la Nacional de Madrid. El enunciado de ambos -el escrito en prosa, y el escrito en verso- fue recogido también por Alenda y Mira, J.: Ob. cit., no s. 684 y 685 . Algunos investigadores del tema de la Inmaculada han recogido estos impresos, como el caso del ya citado Serrano y Ortega,M.: ob.cit., págs.523-528, que menciona otra mascarada de los Plateros en 1622. 
La cuadrilla o copia de los. Plateros, que es la que nos interesa, parece ser que era una de las más fastuosas, y quizá el hecho de desfilar la última şignificase su mayor importancia, ya que, tradicionalmente en los desfiles y procesiones, los últimos son los más importantes.

Además de este testimonio, Ortíz de Zúñiga nos refiere también la procesión, a la que alude entre las otras muchas que hubo en la ciudad, asegurando que a lo largo de estos últimos meses del año organizaron fiestas casi todas las corporaciones de la ciudad, como cofradías, gremios, naciones, y colores, etc. Así desfilaron los franceses, los portugueses, los mulatos, los negros, y hasta los moros y moras lo intentaron, como anteriormente vimos.

En la mascarada del 26 de noviembre, en la que desfilaron los plateros, todos ellos tenían que reunirse en el Alcázar y desde allí iniciar la procesión. El desfile no llevaba imágenes, salvo algún gigantón, sino personas vivas disfrazadas de personajes simbólicos, la mayoría puramente profanos que portaban emblemas de la defensa de la Concepción Inmaculada. Todo ello se apoyaba con música, canciones y danzas. La visión de conjunto que da la procesión es la de una representación teatral donde el arte del disfraz es fundamental, tratando de identificarse cada uno de los participantes con el personaje que le había sido asignado.

Estos desfiles que, como hemos visto, se efectuaron antes del día de la Inmaculada, fueron en realidad un anticipo de la gran fiesta litúrgica que se celebró en los dias 7 y 8 de diciembre en que se estableció por el cabildo eclesiástico la fiesta de la Inmaculada.

El desfile de los plateros, fue la última de las seis, y en realidad el broche final de todas las fiestas que se habían venido celebrando desde el 15 de octubre, en que llegó la noticia de Roma, en las que no habían faltado las corridas de toros y los torneos. Al decir del cronista, la máscara de los Plateros fue la más lucida de todas. Ésta, como las demás hicieron el siguiente recorrido: desde el Alcázar a la plaza de San Francisco, Colcheros, Alameda de Hércules, Amor de Dios, Sierpes, Gallegos, Salvador, Francos y Gradas de la Catedral ${ }^{18}$.

Los participantes estaban agrupados también en cuadrillas, compuestas en su mayoría por doce hombres, que tenían a su cargo una representación de figuras alegóricas o históricas, o bien acompañaban a otra figura principal.

A las dos de la tarde los bedeles fueron por los barrios reuniendo a los componentes de la procesión para acompañarlos al Alcázar, de donde partirían. A las siete salió el cortejo con personajes ricamente vestidos, que se iniciaba con doce criados con antorchas seguidos de música de trompetas y clarines, que precedían a la Fama. Ésta, tocaba un clarín y llevaba alas de plumas de colores, yendo flanqueada por dos bedeles. Seguía a continuación la representación de Sevilla, aún más ricamente vestida de armadura dorada, telas bordadas y suntuosísimo gorro en forma de castillete, en el que se representaba una imagen arquitectónica de la ciudad con sus

18. Serrano y Ortega, M.: ob.cit., pág.474. 
torres y murallas. Según la opinión del cronista la corona era una joya llena de piedras preciosas cuyo valor calculaba en mas de 100.000 ducados. Esta figura, que era prácticamente la más importante del cortejo, a juzgar por la riqueza de su vestido y de su corona, iba en un palafrén sostenida por Hércules y Julio César, fundador y reedificador de la ciudad respectivamente, según la tradición renacentista.

Otra de las cuadrillas representaba a los Doce Emperadores Romanos, a caballo, con cascos empenachados, antorchas en las manos, y ricos trajes de la época.

La cuadrilla de los Negros parece que fue una de las más vistosas, porque todos iban vestidos de raso blanco con el anagrama de María coronado y bordado en oro, con gorros rojos, y con multitud de joyas en los brazos y en el cuello, que destacaban sobre lo negro de su piel. Tras ellos iba el rey Negro, montado en un caballo empenachado.

Parece ser que la cuadrilla que más llamó la atención de la gente, además de ser calificada como la mejor, fue la de los Doce caziques, también a caballo, cuyos trajes eran riquísimos, y rodeando la cara llevaban una especie de rostrillo de plumas de vara y media $-1,25 \mathrm{mts}$.-, así como colgantes de perlas de la nariz y de la barba. A la cabeza de la cuadrilla iba $E l$ Sol, también a caballo, y cubierto de oro y piedras.

A continuación iban los Reyes de armas a caballo, y seguidamente los Franceses, que también componían una cuadrilla de doce, vestidos al estilo de su tierra. Éstos acompañaban al Rey de Francia, que también iba ricamente vestido, y seguido de doce alabarderos.

Los Portugueses parece que echaron el resto y montaron una especie de representación histórica de los reyes de su dinastía. Se iniciaba su cuadrilla con el Alférez Mayor del reino, que llevaba el estandarte con el escudo de Portugal, y luego iban los Reyes de la dinastía portuguesa, vestidos cada uno como en su época, y hechas sus caras a semejanza de las efigies que de ellos se conservaban, pues habían traído retratos de Lisboa para copiarlos. En el cortejo portugués iban también los Duques de Brdganza, los de Aveiro, y el Arzobispo primado de Braga.

Finalmente iba la cuadrilla de Los Cardenales, que habían decretado en Roma la Inmaculada Concepción de María. Delante de ellos iban los dos personajes sevillanos que fueron claves para conseguir la declaración de Roma: Mateo Vázquez de Leca, representado como Doctor en Teología, y Bernardo de Toro, como Doctor en Cánones. En la representación de los Cardenales se había conseguido un gran realismo porque además de vestirlos de rojo, según las disposiciones de la Iglesia, y de adomarlos según su alta condición, se había intentado representar también su edad -generalmente eran ancianos-, o la severidad y dignidad de sus rostros. Entre ellos iba el Arcángel San Gabriel con una cartela que ponía AVE GRATIA PLENA, como personaje directamente relacionado con la Virgen. Cerraban esta cuadrilla el príncipe Don Carlos, vestido de blanco y adornado con gran cantidad de joyas, que en la gorra tenían forma de diamantes, y el papa Paulo $V$, al que precedía la cruz papal de doble brazo. El pontífice iba vestido tal y como correspondía a su categoría, y tal como lo vemos en la pintura coetánea, de rojo, con muceta de terciopelo forrada de armiño y bonete a juego, el cronista nos dice que se había elegido una persona que incluso se le parecía físicamente. 
Acompañaban al Papa los Reyes de España y Francia, cuyos trajes iban tan cubiertos de joyas, que no podía verse el color de la tela.

Finalizaba la máscara con una escolta real y otro grupo de guardia pontificia a cuya cabeza iba un guión rojo con puntas de plata, que en uno de los lados llevaba las armas del Papa, y en el otro letras de oro que decían MARÍA SANTISSIMA CONCEBIDA SIN PECADO ORIGINAL. Tras todo ello un grupo de más de cincuenta soldados cerraban el cortejo llevando lanzas en cuyas puntas lucían banderolas con los colores azul y blanco de la Inmaculada.

\section{VARIANTE DE LA MASCARADA EN PROSA.}

Serrano y Ortega en su ya citada obra sobre la Inmaculada recoge otra mascarada de los Plateros celebrada en $1622^{19}$, que presenta unas características muy semejantes a la anterior, tan semejantes que puede pensarse que podría ser la misma contada por otro cronista, o bien que en 1622 los plateros sacaran otra máscara muy parecida a la ya descrita de 1617. Este investigador, que es que el único que recoge la mascarada de 1622, no la cita en un índice de todos los textos de fiestas utilizados en su trabajo, que coloca al final del libro. Esto es lo que nos ha hecho pensar que sea la misma del 1617 contada por otro cronista.

En la segunda mascarada desfilan nueve cuadrillas, repitiéndose personajes de la primera como La Fama, Hércules y Julio César, el Arcangel San Miguel, la cuadrilla de los Negros, y la cuadrilla de los Indios con Moztezuma y la de los Reyes de Francia. Sin embargo, aparecen otras cuadrillas distintas de las de la primera cabalgata como la de los Caballeros de Malta, la de los Romanos, o la de las Fieras, en la que sus personajes iban disfrażados con telas que imitaban a las pieles de los animales. Otras cuadrillas distintas eran la de los Padres del Antiguo Testamento, la de los Patriarcas antecesores de la Virgen, y la novena y última de la Casa de Austria.

De las nuevas cuadrillas hay que decir que sus vestidos y disposición en el desfile eran muy parecidos al de las demás, pero por ejemplo en la de los Romanos se habían aprovechado las siglas del Senatus para interpretarlas como alabanzas a la Virgen. Así decían: "S anta, P ura, Q uerpo impecable, R eina libre". En la cuadrilla de los Padres del Antiguo Testamento estos iban vestidos de pieles y de hojas, y llevában letreros con sus nombres. La de los Patriarcas estos iban de hebreros y cada uno llevaba en la cabeza atributos de la Virgen, que eran la torre, la ciudad, la fuente, el sol, la luna, etc., expresado con piezas de oro y plata. En la cuadrilla de la Casa de Austria aparecían todos los reyes de España desde Carlos V hasta Felipe IV, que estas fechas ya reinaba, añadiéndosele Rodolfo II, y suprimiendo al Papa. Se dice que esta mascarada salió del Alcázar como la anterior.

19. Serrano y Ortega, M.: ob.cit., págs.523-528. 


\section{LA MASCARADA EN VERSO}

La relación en verso se compone de versos octosílabos que forman un interminable romance, en que se repite con muy pocas variantes la relación en prosa de 1617 , aunque presenta muchos más detalles, y por lo tanto resulta algo más extensa. Resulta muy minuciosa, especialmente en las descripciones de los vestidos, caballos, emblemas, etc., pero además menciona los nombres de algunos personajes, que no aparecen en la proșa. En otros casos, por el contrario, alude indirectamente a personajes descritos en la prosa

Los personajes principales coinciden totalmente, salvo la mención de la Justicia, que según esta versión iniciaba la máscara. Este personaje, a juzgar por sus medidas, -12 varas, es decir 10 metros-, debía ser un gigantón, a la que tan aficionados eran los vecinos de Sevilla. El número de cuadrillas es de seis en ambos relatos, pero en algunos casos no coincide el numero de los componentes, como, por ejemplo, en la recogida de personas previa a formar la procesión en el Alcázar, se mencionan 4 bedeles y 16 lacayos, en el impreso en prosa, y 3 bedeles y 12 criados en el en verso. Pero en realidad no hay cambios en los personajes principales, lo que nos confirma la veracidad del relato.

En el caso de la cuadrilla de los Negros se dice que "eran blancos hechos negros", lo que indica que no eran negros auténticos, sino blancos que se pintaron de negro. No obstante, la identificación con esta raza debió ser muy profunda pues menciona sus instrumentos musicales propios "Maçambiques y Macoas", que les acompañaban en sus danzas propias. Así mismo especifica que su rey era Baltasar, uno de los Reyes Magos, y estableciendo un parelismo entre la Epifanía y la defensa del culto a la Inmaculada.

Con respecto a la cuadrilla de los Caziques o Indios, suponemos que también eran fingidos, sin embargo se dan muchos detalles que demuestran un amplio conocimiento de los pueblos ultramarinos. Así dice:

"Los justillos tan bien hechos/ hechos a la misma usança, tal que dieron hasta embidia/ a los Indios de Guaxaca".

Mas adelante :

"Sus mantos de varias sedas/ puestos a su modo y traça tal, que el mismo Monteçuma/ nunca les dio ventaja".

Parece evidente que los Plateros tenían nociones de la América Española, conociendo la personalidad de Moztezuma, y la fama de la riqueza de la región de Oaxaca.

En el caso de la cuadrilla de los Franceses existe una diferencia de número entre ambos relatos, pues mientras la prosa cuenta doce caballeros, el verso cuenta 11 , 
que identifica con los compañeros de Roldán, ya que éste había sido muerto en Roncesvalles. En ambos textos figura el rey de Francia en el cortejo.

En la cuadrilla de los portugueses nos dice que los reyes eran 17, y entre ellos estaba Don Sebastián. Por el contrario en la descripción en prosa no menciona a los duques de Braganza y Aveiro y al arzobispo de Braga, aunque se aluden indirectamente diciendo:

"Los tres grandes de aquel Regno/que son de su sangre mesma" referida naturalmente à que son familia del rey reinante. Con respecto a la perfección con que se representaron estos reyes hay que hacer notar que en la prosa se dice que las caras de los reyes portugueses habían sido hechas en Lisboa, por lo que como ya dijimos, cabe la posibilidad de que fueran simulacros, o bien que el trabajo de Lisboa se refiera a las máscaras que lucían sus sustitutos.

Finalmente la última y más importante cuadrilla, la de los doce Cardenales, presenta una variante con la prosa en lo que a los personajes reales se refiere. Primeramente el príncipe que aquí se menciona es Felipe $I V$, el auténtico heredero de la corona española, mientras que en la prosa habla de un príncipe Carlos, que no sabemos quién se refiere, ya que Carlos, el hijo primogénito de Felipe II, había muerto en 1568, por lo que nos inclinamos a pensar en un error de la descripción en prosa. La otra variante se refiere a los reyes acompañantes del Papa, que en este caso son Felipe II y Felipe III, el gran defensor de la Fe y su hijo y rey reinante. Por el contrario en la descripción en prosa se habla de los Reyes de España y Francia, que naturalmente en 1617 eran Felipe III y Enrique IV. Esta inclusión del rey de Francia nos parece algo extraña entre otras cosas, porque ya había aparecido en la cuadrilla de los Franceses, por lo que no parece apropiado que se represente dos veces en la misma máscara. En este caso nos inclinamos por la mayor verosimilitud de la versión en prosa.

La última diferencia apreciable es la referida al número de soldados que acompañaban a esta cuadrilla, que es de 300 en el relato en prosa y de 50 en el relato en verso. En este caso no tenemos motivos para inclinamos por una u otra versión, pero tampoco parece una diferencia de gran interés que afectara al contenido de la máscara.

Esta mascarada, que fue pagada por los Plateros, representó ante el pueblo de Sevilla, como puede verse, en una especie de teatro móvil, la fiesta de la Declaración de la Inmaculada Concepción de la Virgen, mezclando la teología, la cultura humanística y la tradición española, con los aspectos pintorescos de la ciudad. Al mismo tiempo se intentaba establecer una clara conexión entre la urbe, la monarquía y la Iglesia. Estas relaciones estaban en uso ya desde el siglo XVI en casi todas las ciudades españolas, pues cada vez que se producía una entrada, o conmemoración de cualquier tipo, referida a personajes reales, se establecían paralelos entre las figuras de los reyes, la historia de la ciudad, y algunos personajes mitológicos, que pudiesen identificarse, tanto con la ciudad como con los reyes. Casos de este tipo 
podemos ver en la entrada de Ana de Austria, cuarta mujer de Felipe II, en Burgos ${ }^{20}$, o en la de Felipe II en Sevilla ${ }^{21}$, por citar algunas de las más representativas, donde los reyes aparecían como dioses romanos, o como personajes medievales conquistadores o defensores de la ciudad.

En el caso de la fiesta sevillana de la Inmaculada, los elementos profanos representados son de clara raíz humanista: la Fama, siempre acompañante de los héroes, y Hércules y Julio César, ambos como creador y restaurador de la ciudad respectivamente. En este sentido, hay que decir que la representación de estos personajes va a ser una constante en todas las festividades reales hasta finales del siglo XVIII, ya que estaban considerados como especie de dioses Manes de la ciudad.

Parece que la figura más ricamente vestida era la de Sevilla, cuya corona representando la maqueta de ciudad, con sus torres y murallas era una verdadera joya cuyo valor se cifraba en 100.000 ducados, y cuyo contenido alegórico era evidente. Esta representación de la ciudad parece estar relacionada con la diosa romana de corona torreada, de la que hoy día se conserva un ejemplar en el Museo Arqueológico de Sevilla.

El tema de los Emperadores Romanos, es claramente renacentista, pues los humanistas del siglo XVI los incluyeron en sus repertorios gráficos, difundiéndolos en todos los campos de las artes. Así los vemos en la arquitectura, adornando portadas o patios, en la pintura, e incluso en la platería.

Después de las alusiones a la cultura humanista vienen los aspectos pintorescos relacionados directamente con la ciudad, como la cuadrilla de los Negros y la de los Caziques, ambas representando personajes existentes en la cosmopolita ciudad de Sevilla durante los siglos XVI y XVII. Negros había en Sevilla parece ser que desde fines del XV, pero mucho más a partir del XVI, a donde habían llegado como esclavos, e incluso habían fundado una de las cofradías más antiguas de la ciudad, la de Los Negritos. En lo que se refiere a los Caziques, es lógico que siendo Sevilla el puerto de embarque para América llegasen a ella de vuelta, no sólo indios, sino pinturas, dibujos y grabados que los representasen, e incluso podría contarse con la descripción verbal de todos los que volvían del Nuevo Continente. Así pues la inclusión de una cuadrilla de indios, $o$ de sus jefes -caziques-, era perfectamente adecuada, lo que ya no parece que fuese absolutamente adecuada era su vestimenta, en la que como podemos ver se mezclaban armaduras romanas con plumas americanas. La representación del Sol como su dios o jefe parece relacionarse con los cultos precolombinos, o al menos con lo que los sevillanos pensaban sobre ello.

$\mathrm{La}$ aparición de las dos cuadrillas de Franceses y Portugueses demuestra que eran los dos países que tenían en Sevilla una representación más amplia o más

20. Sanz,M.J.:"Festivas demostraciones en Nimega y Burgos en honor de la reina Doña Ana de Austria", Boletín del seminario de estudios de Arte y Arqueología tomo XIIX, Valladolid, 1983, págs.375-395.

21. Mallara, J.: Recebimiento que hizo la muy noble y muy leal ciudad de Sevilla a la C.R.M. del Rey D.Philipe N.S.. Va todo figurado con una breve descripción de la Ciudad y de su tierra. Sevilla, 1570. 
poderosa, y que se distinguían del resto de la población vistiendo según la moda de su propio país. En el caso de los Portugueses, tan próximos y tan relacionados con Andalucía, la representación de sus reyes y señores principales fue mucho más amplia que en el caso de los Franceses.

La cuadrilla de los Cardenales era la clave de la máscara, ya que representaba los aspectos religiosos de la fiesta, que hasta llegar a ella habían sido nulos. Los cardenales eran la aprobación romana, la legalidad de lo que los sevillanos habían discutido, y por consiguiente la fulminación de aquellos dominicos que eran contrarios al dogma de la Inmaculada, todavía no declarado canónicamente, ya que esto no ocurrirá hasta el siglo XIX. Las grandes autoridades de la Iglesia -Papa y cardenales- aparecían allí protegidos por los reyes de España, defensores de la Fe Católica y máximos paladines del papado, abandonado ya por la Europa protestante. La alegoría que representaba al rey de España como defensor de la Iglesia se inició ya en tiempos de Felipe II con el famoso cuadro de Tiziano, que se halla en el Prado, y desde este momento la figura del rey de España tuvo siempre esta connotación.

Queda por saber, al no disponer de imágenes gráficas de la mascarada, si todos los personajes eran hombres disfrazados, o si algunas de las figuras eran de madera o cartón. La mayoría, sino todos, por las funciones que realizaban, debían ser personas vivas, ya que tocaban música o iban a caballo, pero otras, como por ejemplo la de la Justicia, según vimos por su altura, debían ser de cartón y madera. El caso de los Reyes de Portugal, que se parecían a los originales, no está claro si eran simulacros, o por el contrario eran personas disfrazadas. En cualquier caso parece ser que alternaban las personas vivas con las imágenes.

Con respecto a los vestidos, no parece creíble que todo lo que relucía fuese oro y plata, aunque el hecho de que lo patrocinasen los Plateros inclina a creer que muchos de los objetos usados en los vestidos y arreos de los caballos fuesen verdaderamente de plata. Asimismo, el precio de la corona de Sevilla, tan elevado, hace pensar que fuese realmente una pieza de joyería, que los Plateros compusiesen para esa ocasión, y que luego fuese desmembrada y usada para otros fines. Sin embargo, no podemos pensar que todos los personajes llevasen joyas verdaderas, porque el gasto no sería soportable para una entidad, que, aunque rica como la de los Plateros, no dejaba de ser un gremio artesanal de la ciudad. Por otra parte al final del texto, como dijimos anterioremente, se hace alusión al "tesoro traído de Indias", diciendo que sin él hubiese sido imposible atender a la mascarada. Hay pues que pensar que quizá los comerciantes ricos o las autoridades ciudadanas pudieran haber contribuido económicamente a la mascarada organizada por las distintas corporaciones, entre las que naturalmente se encontraban los Plateros.

Lo más interesante, sin embargo, es ver cómo el pueblo podía ilusionarse con aquellas imágenes hasta llegar a creer que de verdad veía a los reyes, a los cardenales, al Papa, y a todos los importantes personajes representados. En realidad se conseguía el mismo efecto que con el teatro, incluso puede decirse que era un teatro móvil al que tenía acceso toda la ciudad. 
Desgraciadamente no nos han quedado imágenes visuales de esta impresionante y colorista mascarada, que no podemos reconstruir mas que a base de los documentos analizados, ya que la imagen procesional más cercana a estos acontecimientos data de cincuenta años más tarde, y tiene un sentido muy diferente. Se trata, probablemente, de la fiesta organizada en 1662, con motivo de un nuevo breve pontificio de Alejandro VII em favor de la Inmaculada, y que se hizo coincidir con la inaguración del templo del Sagrario. De estas fechas se conserva un lienzo anónimo en la catedral de Sevilla ${ }^{22}$, que representa una procesión de la Virgen de los Reyes que discurre por delante de las Gradas de la catedral, adornadas riquísimamente para estas fiestas. Allí entre las imágenes de los patronos de la ciudad, de multitud de arcángeles, y de santos de devoción, presididos por un lienzo de la Inmaculada - que al parecer corresponde al que pintó Herrera el Viejo en $1616^{23}$-, se preparó un escenario digno de la mejor imaginación barroca, donde además de las reliquias principales de la catedral, se colocaron multitud de objetos de plata, justamente sobre las gradas. A los lados del suntuoso retablo central se alzaron dos grandes pirámides escalonadas cubiertas por bandejas de plata. Es bastante probable que los Plateros, que tenían parte de sus tiendas justo en frente a las Gradas, participasen en la decoración de este gran espacio con los objetos de plata que tenían en sus talleres y tiendas (fig.3).

Sin embargo, la procesión pintada es puramente religiosa, donde sólo aparecen, además del paso de la Virgen de Los Reyes y las manguillas, personajes eclesiásticos, y algunos civiles importantes, pero nada hay de disfraz, ni de elementos populares, ni profanos, que guarde relación con las mascaradas realizadas en la segunda década del siglo. Éstas se hallaban mucho más cercanas al espíritu profano del siglo anterior, que a la solemnidad barroca del último tercio del siglo XVII.

No queremos terminar sin dejar constancia de la repercusión que tuvieron las controversias teológicas, y los acontecimientos ocurridos en Sevilla, en la segunda década del siglo XVII, ya que parece ser estimularon la devoción a la Inmaculada en toda la ciudad, y especialmente entre el Arte de la Platería. Justamente de estas fechas arranca la profunda devoción que los plateros tuvieron por esta advocación, incorporándola en todos los cultos de su cofradía, e incluso teniendo un altar en su capilla dedicado a ella. Sabemos que en 1622, muy poco después del breve pontificio, y en plena efervescencia de la devoción concepcionista, ellos se comprometieron con los patronos de su capilla, en San Francisco, a pintar un lienzo de la Inmaculada, que se colocaría en uno de los testeros laterales ${ }^{24}$. Más adelante tuvieron también. una pequeña talla, que existía a comienzos del XIX cuando fueron expulsados de

22. Valdivieso, E.: "La pintura en la catedral de Sevilla, siglos XVII al XX", La catedral de Sevilla, Sevilla, 1984, págs. 407-408, Serrera, J.M., Oliver, A. y Portús, J.: Iconografia de Sevilla. 1650-1790, Sevilla, 1989, pág.267.

23. Ibidem, Martínez Ripoll, A.: Francisco de Herrera el Viejo, Sevilla, 1978, págs. 140-141.

24. Sanz,M.J.: El gremio de plateros sevillano. 1344-1867, Sevilla, 1991, doc. $\mathrm{n}^{\circ} 12$, pág.231, Una hermandad Gremial: San Eloy de los Plateros. 1341-1914, Sevilla, 1996, pág. 
San Francisco por la tropas napoleónicas. Pero quizá lo más significativo sea que desde finales del siglo XVII, hasta la desaparición del gremio, en 1867, todos aquellos plateros que querían alcanzar el grado de maestros habían de jurar, antes de ser admitidos como tales, defender el misterio de la Inmaculada Concepción ${ }^{25}$.

\section{APÉNDICE DOCUMENTAL}

Documento $n^{\circ} 1$.

\section{Fiestas del patronato de la Inmaculada. Copia sexta que da cuenta de la masca- rada que los artistas plateros hicieron.}

Una de las señas demostradoras de los generosos, y piadosos ánimos, que los hijos de Sevilla en tan deseada ocasión exercitan, es, que no decaece la emulación en los unos, como experimentaron el fervor en los otros, creciendo ensanchas a los coraçones, para los sumos gastos, pretendiendo siempre exceder los últimos a sus inmediatos. Afirme mi verdad la fiesta que refiero, pues viendo los Plateros la liberalidad de que los dueños del Torneo usaron, hizieron sus diligencias para que una máscara(que despreciadores de la costa, y estudiosos de la curiosidad, ordenaron) fuesse la ocasión más luzida de todas, honrados pensamientos tuvieron, si los lograron, árbitro sea Vuestra Señoría, pues oye, sino vio.

Domingo veyntiseis de Noviembre, no tuvo morador Sevilla que no se combidase a sí mesmo, para gozar deste disfraz, que desde las dos de la tarde a festejar, se començó, pues a essa hora, quatro Bedeles vestidos a la española, con galas libres de calumnia, y dignas de loable aprovaçión, con dieciseis lacayos de librea, que los acompañaban, discurrieron la ciudad por distintos quarteles, hasta juntar la quadrilla que le tocava a cada qual, que junta conducía al Alcaçar, lugar destinado para ordenarse. Acompañava a qualquiera las copias de clarines y trompetas, el Bedel luego a quien antecedía una azémila, que llevava las hachas blancas de aquella quadrilla, adornada de almatargas de seda y penachos de colores, reposteros hechos para la ocasión, sucedía la quadrilla, que contenía doze personajes la de menos.

A las siete de la noche(tiempo oportuno) salio la universidad de todos, admirables y luzidos quanto dessearon. Doce antorchas en manos de tantos criados, con vestidos conformes, procurava que después de la música de trompetas y clarines, se viesse el primer personage. Era la Fama, que entre los dos Bedeles, tocava un clarín, vestida vizarramente, conforme la pintan, con las alas de plumages de colores. Sucedía Sevilla, armada de un coselete dorado, sobre faldones de tela guarnecida con passamanos de oro, basquiña bordada hasta cerca de el pie. El tocado que formava edificio murado con las torres y capiteles que tanta Ciudad contiene, crédito se me dará quando diga que hiriendo las luces de los infinitos diamantes y rubíes que tenía, cegava, pues valía más de cien mil ducados. Llevávanla en un palafrén ricamente encubertado, Hércules y Iulio César, fundador suyo el uno, y reedificador

25. Sanz, M.J.: El gremio de plateros sevillano. 1344-1867, pág.139 y doc. n³5, pág. 301. 
el otro, imitando el trage a su natural, y la particular costa a su grandeza, rodeándoles muchos criados con antorchas, adorno que faltó a ninguno de todos.

Primer lugar ocupó la quadrilla de doze Emperadores Romanos, las cotas de tela boradada, faldones y chias quajados con passamanos de oro, calças enteras de obra, varias en colores, coturnos dorados; en las frentes del coturno, en el pecho de la cota, y en los ombros, de que se asía el manto de velillo de oro y argenterías, mascarones de plata de martillo, coronas de laurel y plata, antorchas en las manos, que clarecían las personas con las que los criados de a pie llevaban: sobervios cavallos, lucidamente encubertados, con cimas de plumas en las testeras, casi competidoras con las que en las cabeças gallardeavan sus dueños.

Razón tuvieron quantos la vieron en agradarse della, sin negar su lugar a la de los Negros, que mostraron ser gente, y gente de lustre, pues otros doze sembraron en vaqueros blancos cifras de oro que dezían MARIA, y adornava la cifra una corona. Salían en los braços negros desnudos, y los cuellos no vestidos(negros también) cantidad de joyas y perlas que a porfía llevavan, a los tocados no faltava la riqueza ni gala, cuyas argenterías brillavan en lo oscuro de la noche, y la luz de las hachas que llevavan ellos y sus criados, con bonetes y jaqueles grana, siendo una tropa alegre, que con música de atabales, en algazara confusa, antecedía al Rey negro con que galas más ricas, ostentava magestad a lo último, excediendo a los demas hasta en los paramentos del cavallo, con ser no poco vistosos los otros; blanco y oro el color de todos, y las penacheras costosamente pobladas de varias y muchas plumas.

Doze Caziques se alçaron con el aplauso del pueblo, que les dio de galanes el primer lugar. Ocasionó aclamación tal, sus ricos quan extraordinarios trages, cotas de tela bordadas de Romanos vestían, cuyos faldamentos enriquecidos con passamanos ricos, bajavan hasta medio muslo, que con lo restante se cubría con justillos de tela de plata: al ombro Tilmas de Primavera, sembradas de argentería, carcajes y arcos dorados. Los tocados aparecieron vistosos, coronando el rostro en redondo con plumas de varias colores, sobrepuestas unas a otras, que hazían buelo por todas partes, de vara y media. Centro de ellas era el rostro tostado el color, de barba y narizes pendientes engastes de perlas. Pobladas yvan las cabezas de los cavallos con penachería(como las de sus dueños) encubertados bizarramente. Todos seguían al Sol, que en primer lugar deslumbrava pues quanto lo cubría era oro y pedrería, su adorno con curiosidad dispuesto. El cavallo arrojava visos de sí, emparamentado a la mesma traça, todo tan bien destribuído, que cada arco estava colocado en parte que no le usurpava su hermosura, el que luzía al lado sin embidia suya. Luego los reyes de armas, con vaqueros de raso azul, passamaneado de oro y plata, en cavallos frisones, lanças de ristre. Doze potentados Franceses procedían otra con calçón justo, y jubón ancho de raso presado, uno y otro , ondeado el campo con passamanos, que formaban celocía. En los claros rosas de velillo de plata, tomada con quatro perlas gruessas, la una y la otra con un broche de diamantes, sombreros valones, plumages de a vara, de las faldas la bueltas guarnecidas con oro, y asidas con broches de diamantes, cavallos encubertados de velillo de plata. El último era el Rey de Francia, vestido de tela rica, con passamanos de oro, jubón y bohemio sembrados de botones de diamantes, en la gorra llevó muchá cantidad, el cavallo blanco con paramentos de terciopelo, cubierto de chapería de plata de martillo. Doce alabarderos le acompañavan, de vistosa librea, representación propria, magestad bien imitada, y adorno admirable.

La bizarría Portuguesa se estrelló en esta ocasión, sacando quadrilla tal , que los juezes censores no quisieron que fuese segunda, decreto que se concedió a todas, $\mathrm{y}$ assi fueron todas primera, y todas mejores. Clarines alentavan la loçanía de los cavallos: el primero era el 
Alférez mayor del Reyno, encubertado de velillo de plata, con laços y flores de diferentes colores, sobre que se mostrava bizarro a maravilla, vistoso de galas, y rico de joyas. Enarbolava. el Estandarte en que bordava las Quinas Portuguesas. Los Reyes de Portugal luego, observadores de sus Monarquías, conforme al tiempo en que reynaron, guardando en los trages el uso de aquella era, armados unos, los coseletes de tela, vestidos otros las ropas de brocado. Gastaron en los vestidos riqueza sin tassa, y los rostros eran naturales, copiando los retratos originales, que traxeron con tal fin de Lisboa. Los Duques de Vergança, Avero, y Arçobispo de Braga primado del Reyno, acompañavan, para aumento de la magestad, no decresciendo en riqueza, quando en estado descreciessen.

Último lugar llevó la quadrilla de los Cardenales de la junta, que decretaron el silencio impuesto en los labios de quantos no publicaren la Limpieza de MARÍA Santísima en su Concepción. Las copias de ministriles y clarines vestían de grana, largueados con passamanos de oro los vaqueros. Primero representavan dos en ábito Clerical, con borla y capirote, uno de Teología, y otro de Cánones, a Don Mateo Vázquez de Leca; Arcediano de Carmona, y al Padre Bernardo de Toro, personas, que animadas de Espiritual zelo, se expusieron a peregrinar por Cortes Reales, y Curias Pontificias en esta demanda, reduziendo ánimos, y advocando voluntades, que envestidos de su mesma piedad, aceleraron el efecto pretendido, y devidamente celebrado. Los doze Cardenales seguían en mulas, con gualdrapas y tocas carmesíes, cubiertas de chapería de plata, y fluecos de oro, unos afectando la ancianidad en lo agoviado de el cuerpo, otros la gravedad de los severo del semblante, y todos el gusto en la acción devota que exercitavan, sotanas de grana cubrían roquetes de olan bordados, los mantos y mucetas del mesmo color, a quien imitava el de los çapatos, guantes y capelos, hasta los criados(que llevavan mucho número de antorchas blancas) vestían carmesí. El Arcangel San Gabriel particular de adorno y proprio en el trage, demostrava una targeta con el Ave María gratia plena iluminada. Sucedía el Príncipe Don Carlos, vestido de tela rica, blanco el color, capa, calça, jubón y coleto, el campo sembrado de casi infinitas joyas. La gorra adornada de estrellas, que no era posible ser Diamantes arrojando tanta luz de sí. El Cruzero del Sumo Pontifice denotava ser el inmediato a él la persona que representava la Beatitud de Paulo V con tan única propiedad que en las acciones naturales se assemejaban los dos, y en el rostro, que mucho que no difiriessen en el trage, sotana carmesí, roquete delgado, muceta de terciopelo carmesí, como el bonete redondo, forrados ambos de Armiños. Ocupaban los lados los Reyes de España y Francia, los cavallos encubertados con paramentos de terciopelo negro bordado, y las personas con galas graves, y sumamente ricas, en quien las muchas piedras y perlas impedían el conocimiento de la color, o tela sobre la que yvan, afirmo a V. Señoría, que tanto precioso como en sí llevavan, basta a dar a esta Ciudad nombre de riquíssima entre las del mundo. Y para lo mucho que gastaron, ansí ellos como los demás devotos que señalaron su devoción, oficiosos en regozijos, y liberales en la costa, fue necessario que V.Señoría en esta ocasón, traxesse de Indias el mucho tesoro que traxo, pues con menos no se pudiera acudir a tanto. Cercava a los tres Monarcas la guardia de archeros y alabarderos con proprias libreas, y fenecía la magestad de esta quadrilla, con la guarda de a cavallo del Sumo Pontífice, que algo apartados de él, seguían al Capitán de a cavallo, armado con un bastón en la mano. Sucedían el Teniente de Capitán de la guarda, que llevava un Guión quadrado carmesí, cercado de puntas de oro y bordado, a un lado las armas de nuestro Santíssimo Padre Paulo quinto, y al otro de letras de oro muy grandes MARÍA SANTÍSSIMA CONCEBIDA SIN PECADO ORIGINAL, luego más de cinquenta en 
número, confuso el orden, coletos de Ante vestidos, sombreros con crecidos plumages ricos. Dos pistolas pendientes del tahelí, botas de rodillera, y lanças en las manos, con vanderas de dos puntas, colores de la Concepción, azul y blanco...Impressa en Sevilla, Por Gabriel Ramos Bejarano, en Cal de Génova: En este año de 1617.

Biblioteca Capitular y Colombina, Sevilla.

\section{Documento $\mathrm{n}^{\circ} 2$}

Relación verdadera de la fiesta y regocixo que esta insigne ciudad de Sevilla hizo a la Inmaculada Concepción de la Virgen María Señora Nuestra, concebida sin mancha de pecado original, y costosa Máscara que la Platería della hizo. Impressa con licencia, en Sevilla, por Gabriel Ramos Bejarano, En la calle de Génova. En este año de mil y seyscientos y diez y siete.

No quiero del Sacromonte/ Parnaso, flores, ni rosas, para que con sólo olellas/ den fuerça y vigor mis obras sólo quiero que me ayude/ una Ninfa, una Señora que tiene la luna al pie, / y de estrellas se corona. Aquella Madre y Doncella/ Limpia y Pura, cuya historia es declarar la grandeza/ de una máscara costosa. Que la insigne Platería/ desta antigua Babylonia, desta Sevilla que al fin/ es ciudad mejor que todas. En ella pienso contar/ sin quitar ni poner cosa, los gastos tan excesivos, $/$ y quadrillas milagrosas. El modo de todo y trages,/ que a la nación más remota sé que causaría contento,/ y más a lo demás devota. El gasto y fiesta que hizieron/ entre tan nobles personas, de los plateros insignes/ passó y fue de aquesta forma. LLegó a los quince de otubre/ un Buleto, que de Roma Nuestro Padre Santo enbía/ en favor de la Piadosa opinión, que favorece/ a una Reyna, que fue Esposa del Sacro Espíritu Santo/ candidísima paloma Estendiose en la Ciudad/ esta nueva tan dichosa, tan desseada de todos/ con regozijos y costas. Encendieron luminarias,/ haciendo juegos y bombas, de artificios que tal suben/ buscando su Esfera propia. Ordenan los ciudadanos/ revolviendo las memorias, hazer Máscaras diversas/ dinas de Palma y corona. No quedaron los Conventos, / ni se olvidaron Parrochias, de celebrar el contento/ con las santas ceremonias. Qual haze bello Otavario,/ qual el Sacro templo adorna de doseles, tal, que suben/ con el deseo a la Gloria. 
$\mathrm{Y}$ después de todo aquesto/ apercibiendo las cosas necessarias, se aperciben/ los artífices de joyas.

Señalan el tiempo y día/ y la persona curiosa sino se enfada verá/ salir la Máscara toda.

\title{
Segundo Romance. De las entradas de las cuadrillas en el Alcáçar
}

\author{
A Veyntiseys de Noviembre,/ que Domingo fue este día \\ arrojaronn su grandeza/ los Plateros de Sevilla. \\ Salieron casi a las tres/ con libreas muy luzidas, \\ los tres Bedeles que fueron/ a los que a todos regían. \\ Yvan todos muy bizarros/ con galas muy peregrinas \\ vestidos a lo Español/dando a todo el mundo envidia \\ Llevavan cuatro lacayos/ cada uno, y estos yban \\ de la color de sus años/ diferentes en divisas. \\ Pasearon la Ciudad,/ y al mismo tiempo que Cintia \\ buscava a la hermosa Venus/ van metiendo las cuadrillas. \\ La grandeza con que entraron/ no se si la lengua mía \\ podrá pintar, pero si/ como testigo de vista. \\ Metió pues cada Bedel/ por el orden que tenía \\ las Quadrillas que le tocan/ desde donde se vestían \\ hasta el Alcaçar real/ que es a do se recogían, \\ tan bizarros y tan galanes/ que fue mucha gallardía. \\ Yva su Bedel delante/ y tras él luego seguían \\ las trompetas y un Clarín,/ y copia de Chirimías. \\ Una acémila tras ellas/ llena de plumas tan vivas, \\ que una cosa es declarallo/ y otra su mucha estima. \\ Llevava encima sus hachas/ puestas en orden, y encima \\ un repostero bordado/ con fuerza de valentía, \\ a quien apretaba todo/ cuerdas de la color misma, \\ con sus garrotes de plata/ que fue asombro de Sevilla. \\ Tras la acémila sus doce/ o la cantidad que yvan \\ mas galanes que se vieron/ en Máscaras ni salidas. \\ Todos de aquesta manera/ se juntaron donde privan \\ la vista, ver tanta gala/ con sus hachas encendidas \\ El orden y la manera/ me de lugar que aperciba \\ la memoria, y que a otro Canto/ el yr saliendo remita.
}

\section{Tercer Romance. De la salida del Alcaçar}

Fue del Alcaçar saliendo/ dando primero a su plaça vuelta la Máscara insigne/ digna de ser celebrada. Fueron saliendo primero/ doze criados con hachas, 
alumbrando a la Justizia/ que sería doze varas.

A quien siguen las trompetas/ que con sus libreas varias pregonaban la grandeza/ con sólo el viento tocadas.

Siguieron por consiguiente/ dos Bedeles cuyas galas puede Nápoles callar/ y el mundo tenerse a raya.

Llevavan la Fama en medio/ tan vistosa y adornada, vestida costosamente/ y en extremo muy bizarra, con sus dos alas de plumas/ puestas con industria tanta y artificio, que tal puso/ silencio a la misma Fama. Tocava un claro clarín/ y tan diestra le tocava que sacava de su centro/a la misma Diosa Palas. En un brioso cavallo/ con tan rica encubertada que en ver a entrambas las dos/ queda la gente admirada. Siguió tras ellas Sevilla/ que aquí se cifró el Mapa de dezilla Non plus ultra/ de su modo fuerte y traça. Yva armada un coselete/ porque así se pinta armada Imitando a la Belona/ hija del Dios de Batallas. Era el coselete hecho/ todo de labor gravada, dorado, y a tanta costa/ que arrojava vivas llamas. Llevava los faldamentos/ por encima de una saya tan costosa por ser tela/ de mil resaltos bordada. Pues querer significar/ de la cabeça las galas, y las joyas de diamantes/ ellas mismas muestras davan. Yva encima de un brioso/ cavallo con su gualdrapa tal que dos mil bendiciones/ de los que la ven alcança, síguenla sus fundadores/ que los lleva a sus espaldas, Hércules y Julio César/ con sus columnas e basas. A lo romano vestidos/ con tal brio y arrogancia, que bien pudieran los muertos/ rendirse a sus mismas plantas Tan gallardos en extremo/ que bien la vista se paga, y se admira en sólo vellos/ y con callar los alaba. Siguieron luego los Doze/ emperadores, Monarcas, a cuyos yugos tuvieron/ sujetas entrambas Asias. Tan galanes y vistosos/ con vestiduras Romanas, hechas de costosas telas/ que cal de Francos lo canta. Tanta costa en guarnición/ tanta grandeza de calças, de diferentes colores/ todo a costa de sus casas. Sus mantos a lo Romano/ y en los dos ombros llevavan sus Mascarones, insignias/ de Roma su Antigua Patria. Cada uno en un Escudo/ el nombre suyo declara, que en el diestro braço lleva/ escrito con letras claras. Do va escrita una Quintilla/ toda ella en alabança, de la Inmaculada Virgen/ reservándola de mancha. Sus coronas de laurel/ honra y premio de batallas, que no hay mas que desear/ ni pedir la vista humana. En poderosos cavallos/ Andaluces, cuyas aguas 
el sacro Guadalquivir/ les dio pasto en sus crianças. Adreçados por extremo/ con sus cubiertas sembradas de mil flores de seda/ sobre velillos de plata.

Llevavan doze lacayos/ con libreas y con hachas, los de a pie y los de a caballo/ cera mucha, y toda blanca Siguioles otra quadrilla/ con la apariencia más rara, que se a visto con regozijo/ porque fue extraordinaria. Fue aquesta de doce negros/ con tal gallardía y graçia, que alegró mucho a la gente/ dexando a toda pagada. Eran blancos hechos negros/tan relucientes las caras, que a fe que dieron deseo/ a mas de a quatro preñadas. Llevavan sayos vaqueros/ blancos más que una Quajada, de tafetán todos llenos/ de muchas cifras doradas, que declaraban MARÍA/ fue en su instante reservada, de la culpa original/ pensamiento heroyco y traça. En los cuellos llevaban puestos/ muchas joyas de Esmeraldas, y de Diamantes y Perlas/ en los braços muchas sartas. Mantos açules, y atrás/ que sobre el cuello y la espa(l)da les colgaba, y del bonete/ una toca muy bizarra.

Los cavallos de lo mesmo/ tan vistoso que no acaba, el entendimiento humano/ de alabar esta Esquadra. El Rey Baltasar les sigue/ que si vino a rendir parias, a Belén, agora viene/ a defender esta causa.

Los lacayos lleva negros/ con xaquetas coloradas, y los botones de los mismo/ y los calçones de Olanda. Llevavan sus instrumentos/tamborilillos y flautas, Maçambiques y Macoas/muy metidos en sus danças. regoxijó mucho al pueblo/ y después de esta passada, passó otra más peregrina/ que fue la nación Indiana. passaron sus Ministriles/ y tras ellos luego passa una figura de un sol/ cosa nunca imaginada. Arrojava de si rayos/con tal fuerça y tal pujança, que la mas gente pensó/ ser Faetón que otra vez baxa. Síguenle doze Caziques/ con las galas más bravatas, que puede contar mi pluma/ ni otras quatro que no bastan. Llevan sus cotas de telas/guarnecidas y sembradas con passamanos de oro/ con trezientas mil lazadas. Los justillos tan bien hechos/ hechos a la misma usança tal que dieron hasta embidia/ a los Indios de Guaxaca. Las plumas de la cabeça/ en derecho son de a vara y de lo ancho en redondo/ mas de a vara y media passan. Llevavan en las narizes/ joyas de perlas colgadas sin otras mil de diamantes/ en los braços y gargantas sus mantos de varias sedas/ puestos a su modo y traça tal, que el mismo Monteçuma/ nunca les dio ventaja. Llevaban sus arcos al ombro/ por ser sus antiguas armas, 
y sus carcaxes de flechas/ echados atrás con gracia.

Los cavallos en que yvan/ al viento veloz igualan

tan adreçados de plumas/ que, en ver tanto el mundo pasma.

De a pie llevan doze indios/ que los sirven y acompañan, vestidos al mismo trage/ en sus cintas sus macanas.

Passó la quarta quadrilla/ que no se como pintalla, según yva de costosa/ que eran la gala de Francia.

Eran de tan sólos onze/ que dexaron en Navarra al que hazió a Galalón/ que temieron otra caça. Fue aquella quadrilla insigne/ con mucha costa de galas tal, que jamás no se vio/ a lo Francés otras tantas. Passó primero un Clarín/ con su vaquero y gualdrapas de raso azul largueado/ con passamanos de plata, a quien siguieron de improviso/ dos bizarros reyes de Armas con vaqueros de lo mismo/ y en sus dientes diestras lanças. Tan briosos y bien puestos/los cavallos con coraças, a modo fuerte y posturas/ que se arrojan a batalla. Siguieron los Potentados/ con la fuerça y arrogancia que gallardean Fanceses/ quando quieren ganar fama. Passaron de dos en dos/ en cuerpo, que cierto igualan a la misma admiración/ talle, brio, modo y bravas. Yvan vestidos de Raso/ azul y con costa tanta de guamición tal, que el fondo/ con la vista no se alcança.

Luego en los compartimientos/ de unos blancos que quedavan una rosa con un Diamante/ con un velillo de Nacar.

Tan llenos de pedrería/ que para creello basta, el dezir que son Plateros/ que lo tienen en sus casas. No quedó joya ninguna/ que en tal ocasión no salga, sin que se alquile o se busque/que ellos nunca alquilan nada Yvan todos a la brida/ con sus espuelas doradas, espuelas a lo Francés/ y al cuello vistosas vandas. Los cavallos adornados, / tan briosos que se igualan a los Baviecas del Cid/o a los mejores de España. Yvan adereçados todos/ de cubiertas extremadas, y plumas en las testeras/y florones en las ancas. Su delfín les sigue luego/ su Rey, Señor y Monarca, más galán que el mismo Sol/muro de la Ley Christiana. Vestido todo de tela/ que el gran Nápoles, y Italia, le rindieron los bordados/ de jubón, ropilla y calça. El bohemio de lo mismo/ sembrado muchas lazadas de perlas en él, y en gorra/ sirven por cayrel dos sartas. Yva en un cavallo blanco/ a quien cubre una gualdrapa de terciopelo cubierta/ de Flor de Lises de plata.

Cercaban a su persona/ los soldados de su guardia que eran veynte alabarderos/ sin doze pagas con hachas. Los Potentados también/ dieron sus libreas bravas 
a los criados de a pie/ coste mucho y bolsas francas.

Rematose esta quadrilla/ y el gran Portugal me llama para que pinte la suya/ y aquí mi pluma repara, que para tratar de Reyes/ diez y siete, que es la esquadra temo porque a Dios y Reyes/ el temer la ley lo manda. la calle donde los vi/ a este mismo tiempo paran, y pues ellos hacen alto/ también mi lengua descansa.

\section{Quarto romance. En que se remata toda la Máscara}

Fue siguiendo por su orden/ a la quadrilla Francesa la famosa Lusitana/ toda llena de grandeza pasó un bizarro Clarín/ muy galán en la librea y el Alferez Real del Reyno/ con su estandarte en su diestra sobre un hermosos cavallo/ con tan hermosa cubierta despulin de plata y oro,/ llena de flores de seda Diez y seiete reyes siguen/ por su orden y en la era que regnaban cada uno/ al natural representan Todos llevan coseletes/ hechos de costosas telas, tan guarnecidos de oro/ que la vista embota y ciega tanta de la Rosa en braço/ tanta de la calça entera tanta variedad de gala/ tanta corona y bien puestas tanta joya de Diamantes/ tanta barva y cabelleras sacadas del natural/ dentro de Lisboa hechas. Yvan todos tan costosos/ y el postrero la presencia del famoso Sebastián/ que bien conoció la guerra. Los cavallos escogidos/ y tan extremos que llevan medio mundo en cada uno/ según su adreço y testeras.

Los tres grandes de aquel Regno/ que son de su sangre mesma los acompañan y siguen/ arrojando mil centellas.

Los criados qual de Reyes/ de quatro en quatro en hilera más galanes y briosos/ que vieron las Portuguesas. Siguioles otra quadrilla/ la mejor y más moderna que se a visto en nuestra España/ en regozijos ni fiestas Passaron sus ministriles/ escogidos y de prueva con sus vaqueros de grana/ guarnición en ellos bella. El Emabaxador les sigue/ que desde el cielo a la tierra fue el mensagero de paz/ que nos confirmó las treguas el que dixo AVE MARIA/ y prosiguio GRATIA PLENA viene oy a defender/ una gran heroyca empressa que si Miguel valeroso/ contra la infernal sobervia se opuso, quien como Dios?/ Gabriel quien como mi Reyna? Llevaba un escudo fuerte/ con una blanca Açuçena Divisa antigua y Blasón/ y por remate este letra Soy embaxador de Paz/ que yo truxe a la tierra 
y para siempre jamás/ queda acabada la guerra.

A sus dichosos lados/ por sus Acólitos lleva

a un Bernardo y a un Mateo/ personas de grandes prendas

son también Embaxadores/ pues a costa de su hacienda

dentro de la corte Romana/ que se de por fe dessean.

Yvan vestidos los dos/ con sus Lovas reverendas, y por el cuello y los ombros/ dos diferentes Mucetas.

Al valeroso Arcediano/ por ser de Leyes su ciencia es verde, y también la borla/ que en su bonete se muestra. La del comapañero es blanca/ pues es Teología perfecta medicina para el alma/ si es que della se aprovecha.

Fueron con tal gravedad/ aunque están tan lexas tierras parecieron ellos mismos/ porque muchos lo confiesan. Fuelos siguiendo quatorce/ Cardenales, que mi lengua no sabe por donde empiece/ que para tanto es pequeña. Los Capelos que llevaban/ eran tales que pudieran honrar a qualquier Christiano/ el provecho de su seda. Las Alvas todas bordadas/ y las más dellas con Perlas y tanta punta y encaxe/ de valientes manos hechas. Los sombreros carmesíes/ con tanta borlas que cuelgan, representsando entre todos/ una magestad inmensa. Las Colas de los Capelos/ hasta el mismo suelo llegan por encima de las mulas/ que en extremo señorean. Eran en extremo todas/ adreçadas y dispuestas con gualdrapas carmesíes/ sembradas todas de Estrellas de la plata que el Pirú/ rinde a España de sus venas. Los criados de lo mismo/ y entre todos mucha cera. llevó esta insigne quadrilla/ para salir más entera al Príncipe Don Felipe/ Quarto en nombre, Fama eterna. Yva vestido de blanco/ de una muy costosa Tela con suma de guarnición/ con calça, bohemio, y cuera, en un brioso cavallo/ con una gualdrapa llena de chapería de plata/ y él en sí mucha grandeza. Siguiole luego el Guión/ del Piloto y de la Iglesia, que le llevaba un legado/ persona de grandes letras. detrás de todos siguió/ con magestad y reverencia nuestro Pontífice Paulo/ honrando con su presencia. La grandeza que llevava/ era cosa tan suprema de pontifical y adreço/ desde el pie hasta la cabeça, alva que a la misma alva/ con tanta blancura afrenta bordada de canutillo/ de Oro, Plata, Seda y Perlas. Yva en un cavallo blanco/ con una gualdrapa puesta realçada de bordadura/ y de tercipelo ella. Lleva un rico pectoral/ en el pecho de ocho piedras tal, que el mismo Padre Santo/ sólo es digno de tal prenda. Acompáñanle a los lados/ los dos muros y defensa 
de la Fe, los dos Felipes/ que al hereje ponen rienda.

La magestad del Segundo/ lleva a la mano derecha que es muy justa obligación/ y a su hijo a la siniestra. Sacaron los dos tal gala/ que no se si decir pueda la grandeza de las joyas/ que fueron muchas y buenas. $\mathrm{El}$ adreço de las gorras/ claças y jubón de telas tal llenas de bizarría/ y ellos que la representan. La guardia cerca a los tres/ puesta en torno haciendo rueda con alabardas gravadas/ las armas de cuyas eran. Las libreas peregrinas/ tantas hachas, todas hechas con letras que declaravan/ de la Virgen la Limpieza. Passó la postrer quadrilla/ por remate la postrera que fue la guarda del Papa/toda la gente de guerra Passó una Trompeta delante/ a quien sigue en delantera un gallardo Capitán/ con su bastón o gineta, va armado de punta en blanco/ unas armas Milanesas tan bien puesto en su cavallo/ que hacía temblar la tierra. Los soldados de a cavallo se siguen/ y en dos hileras tan galanes que por Dios/ que engrandecieron la fiesta con coletos guarnecidos/ y en los cuellos golas puestas con vandas de mucho coste/ sin mil galas y presseas. Llevan las lanzas en ristre/ y en las puntas vanderetas la mitad de color blanco/ y açules las otras medias. En cavallos valerosos/ con plumas en las testeras y a lo soldado terciados/ en los sombreros las llevan. Los arçones con mochilas/ con sus Pistolas Francesas todos con tal propiedad/ que no hay mas que hacerse pueda. Las personas que llevava/ lo mas con que se me acuerda que por Dios que las conté/ y eran cerca de trezientas. Fueron todas las quadrillas/ dando letras muy discretas y todas en alabança/ de la Inmaculada Reyna. Gastaron todo este gasto/ costeado de su hazienda, en servicio de la Virgen/gran Señora y Reyna nuestra. Passearon la ciudad/ y después de dalla vuelta se volvieron a sus casas/ rematándose la Fiesta.

Fin a Honra y Gloria de Dios Nuestro Señor, y de su Bendita Madre, Concebida sin mancha de pecado original. 


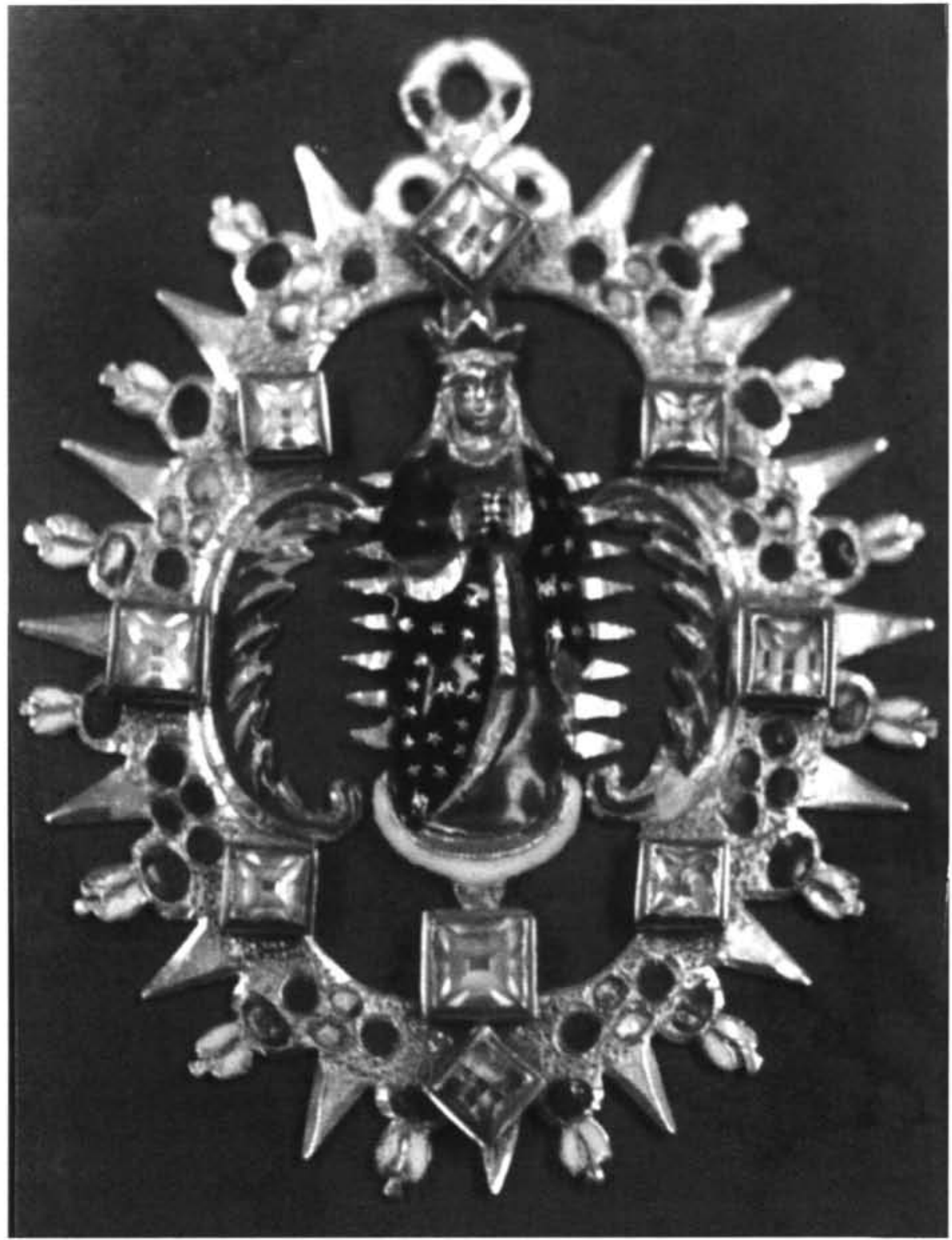

Fig. 1

Medalla de la Concepción. Oro, esmaltes y piedras. $1^{\text {er }}$ cuarto del siglo XVII. Tesoro de la Virgen de Gracia, Carmona. 


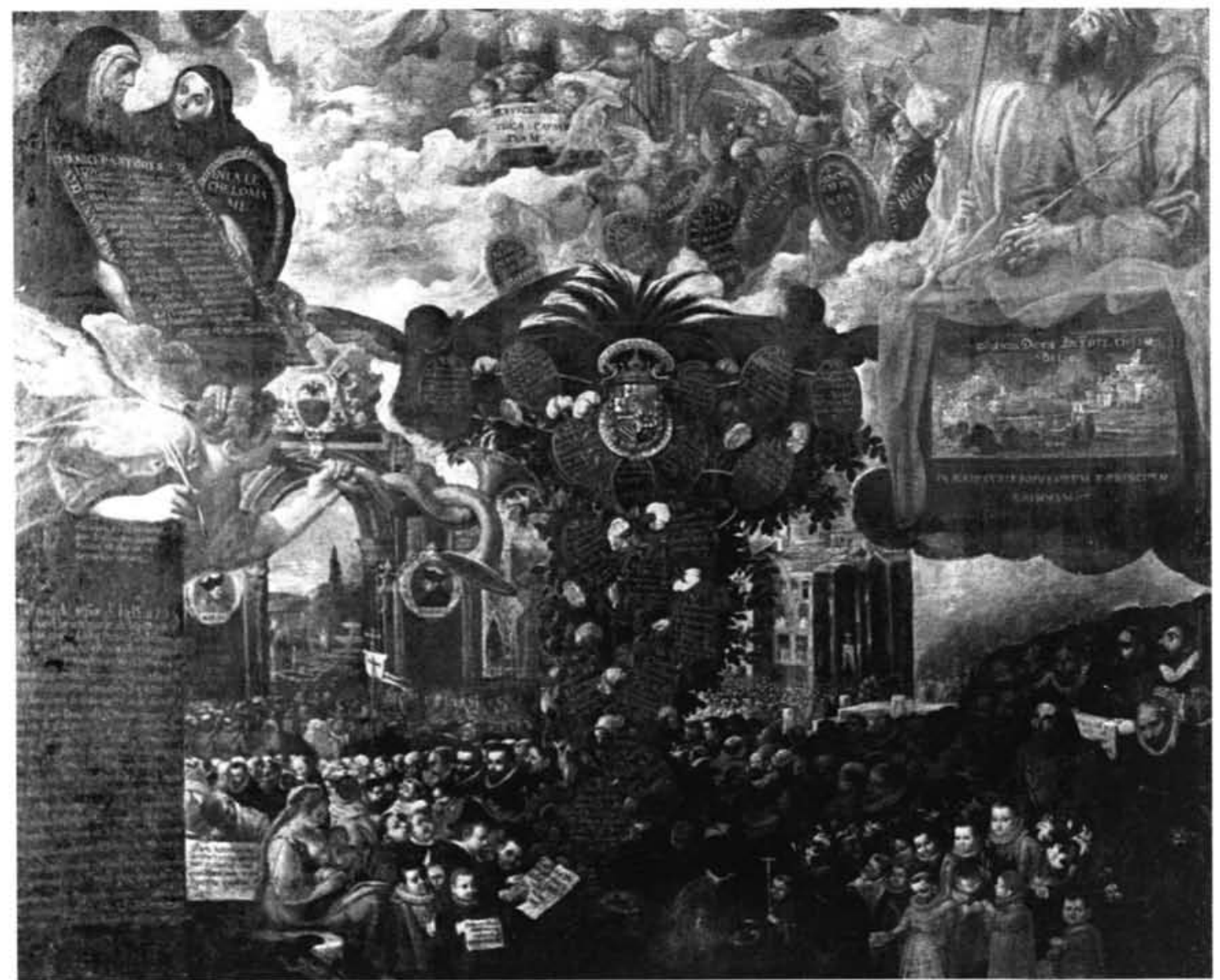

Fig. 2

Lienzo anónimo que representa la procesión de la Virgen de los Reyes desfilando por delante de un altar levantado en las gradas, que preside la Inmaculada Concepción. Hacia 1662. Catedral de Sevilla 


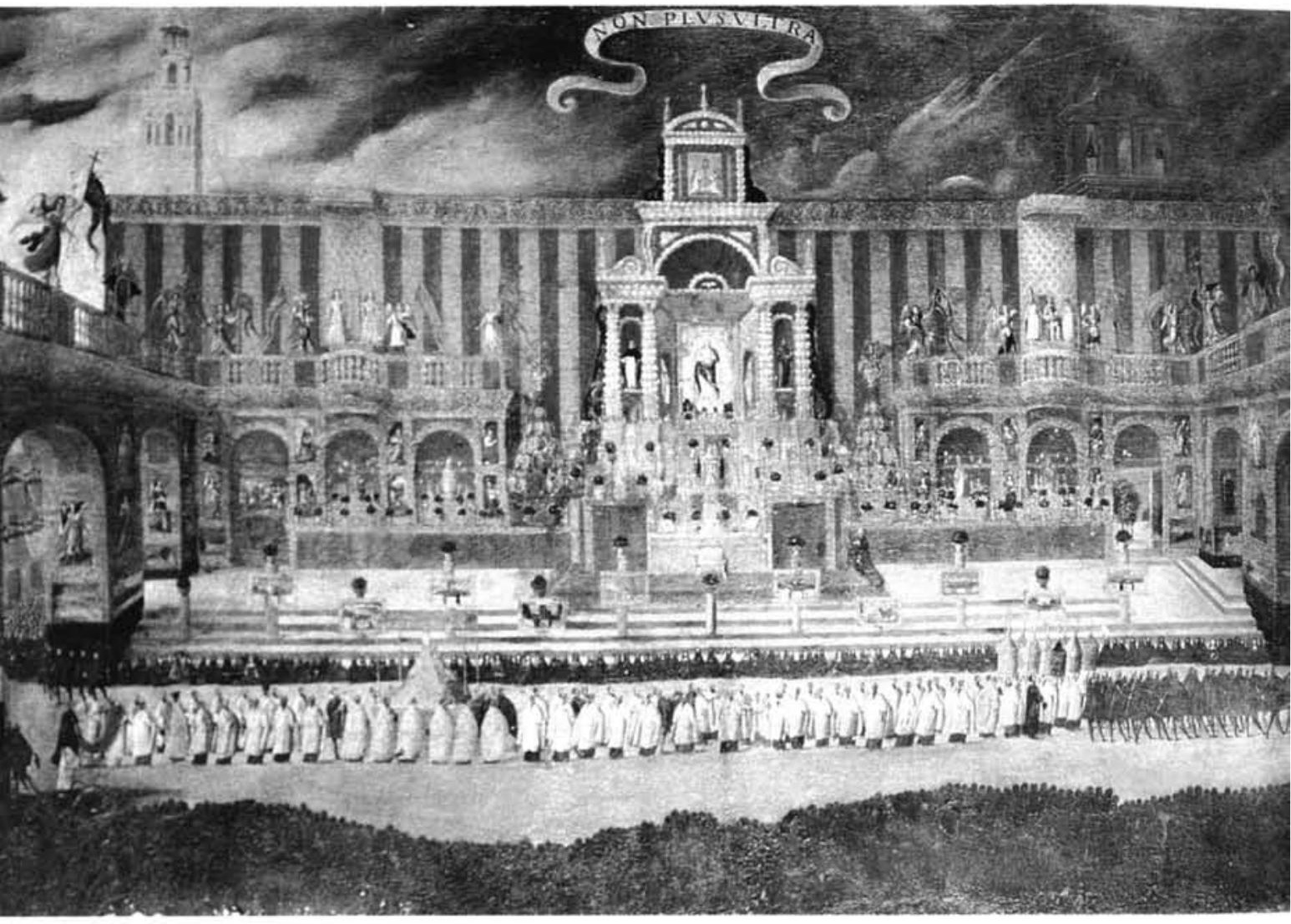

Fig. 3

Lienzo de Juan de Roelas, que representa a la Inmaculada Concepción y el pueblo de Sevilla, 1616. Museo de Escultura de Valladolid. (Detalle). 